\title{
Guide to Using the Free Rent Calculator
}

Peng Liu, Luoyi Su, and Jan deRoos

\section{EXECUTIVE SUMMARY}

n this step-by-step guide, we show you how to use the Free Rent Calculator, which provides an accurate, visual means to quantify the impact of concessions in commercial leases based on the market conditions and landlord's risk profile. The calculator allows both landlords and tenants to benchmark the impact of free rent, tenant improvements, and moving allowance on a given set of the asking and offering rents. The calculator determines the resulting effective rent, which is equivalent to the tenant paying a constant base rent over the entire lease term. ${ }^{1}$ The effective rent serves as a comparison benchmark, allowing users to quickly see the impact of changes to the asking rent and concession package. The tool works by allowing users to specify the structure of the rental payments, tenant improvements (TIs), and the moving allowance, and then computes the maximum free rent period in light of the specified lease terms and concessions.

Landlords can use the tool to fine-tune the concession package by determining the appropriate level of free rent that seems attractive without increasing exposure to tenant default. Tenants can use the tool to optimize the free rent and concession structure to create the most desirable pattern of monthly cash outflows from the available options.

\footnotetext{
1 The use of "effective rent" as a comparison benchmark is well documented in the real estate literature, as evidenced by its use in the classic real estate textbooks. For example, see: chapter 9, "Income-Producing Properties: Leases, Rents and the Market for Space," in W.B. Brueggeman and J.D. Fisher, Real Estate Finance and Investments, 14th edition (New York: McGraw Hill/Irwin, 2011), pp. 273-277.
} 


\section{Guide to Using the Free Rent Calculator Peng Liu, Luoyi Su, and Jan deRoos} $\mathbf{B}_{\text {tabs in the spreadsheet, "Free Rent" and "Cal," that handle user input and calculations. }}$
efortere

The "Free Rent" tab is the main tool component where you adjust leasing assumptions and get real time feedback on the suggested amount of free rent; the grey fields are for input, the yellow fields are output, and a green box indicates that the input field on its left is a dropdown menu. The "Cal" tab performs background calculations while you are entering data; you only need to use this tab in two situations: (1) to see the more precise number for the free rent period (without rounding), and (2) to change the defaults for Indexed leases (CPI or Porter's Wage).

Below we outline the three steps to navigate through the tool. The steps are (1) finding a benchmark, (2) entering data, and (3) interpreting the results.

Three Steps to Using the Tool

Step 1. Finding Benchmark via "Market Information"

\begin{tabular}{rr|} 
Market Information & \\
Property Location & New York, NY \\
\cline { 2 - 2 } Property Type & Office \\
Year & 2013 \\
Market Rent (S/SF) & $\$ 62.12$ \\
\hline
\end{tabular}

The top panel, "Market Information," presents the market rent for your property's submarket, type, and year using a REIS commercial real estate lease database. The tool automatically updates itself on a quarterly basis. The Market Rent output (in yellow) serves as a helpful reference and benchmark during negotiation process and is used to calculate the optimal amount of free rent.

\footnotetext{
2 To enable Macros manually in Excel 2010 for the PC, click the "File" Tab, then "Options", then "Trust Center", then "Trust Center Settings", then click the "Enable All Macros" button.
} 
Step 2. Entering Data via "Lease Contract Information"

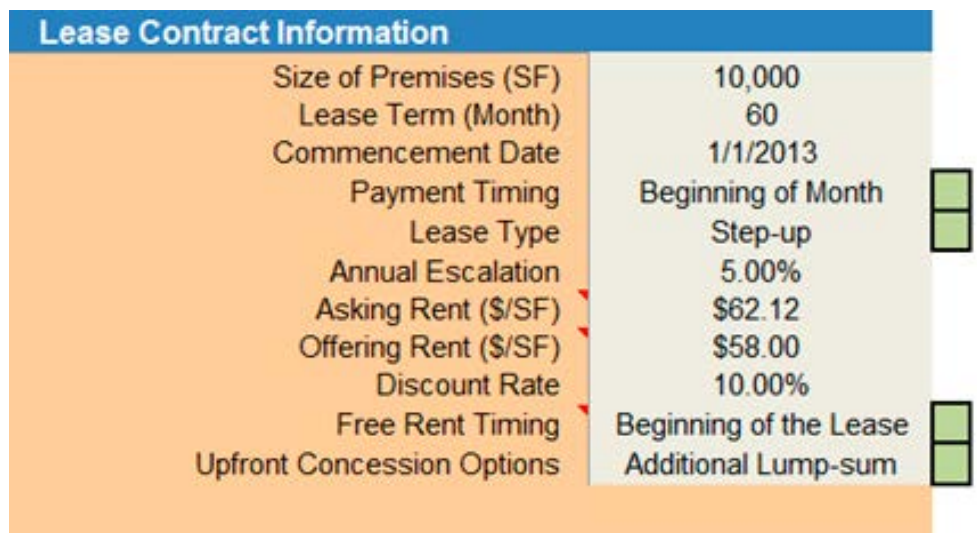

The "Lease Contract Information" panel is the main input section to the Free Rent Tool. Here you change the default input parameters based on your own lease provisions. The following are the descriptions for the input variables. Note that the inputs change, depending on the various options chosen to specify the lease structure and the concessions.

- Size of Premises: the size of space to be leased, in square feet.

- Lease Term: the length of the lease, in months.

- Commencement Date: the start date of the lease.

- Payment Timing: specifies whether rent payment is at the beginning or end of each month.

- Lease Type: specifies the annual rent adjustment method with the three options detailed below:

- "Flat" means the same monthly or annual rent over the entire lease term;

- "Step-up" means the rent is increased each year by the percentage specified by the "Annual Escalation"; and

- "Indexed" provides two index options-CPI and Porter's Wage.

For the CPI index:

$\begin{array}{rr}\text { Lease Type } & \text { Indexed } \\ \text { Index } & \text { LPI Lease Factor }\end{array}$

The "Lease Factor" specifies the percentage adjustment of the index (e.g., 100\% indicates the multiple of change in the index, meaning that if CPI increases by $2 \%$ then rent increases by $2 \%{ }^{\star} 1=2 \%$ ); to change the default CPI, please find the CPI Index Settings in the "Cal" tab and adjust CPI annual change percentages (Year 1 is the base line and should always be blank as shown below).

\begin{tabular}{cc}
\multicolumn{3}{c}{ CPI Index Settings } \\
Year & \% \\
Change \\
1 & - \\
2 & 1.93 \\
3 & 1.89 \\
4 & 1.86 \\
5 & 1.82
\end{tabular}




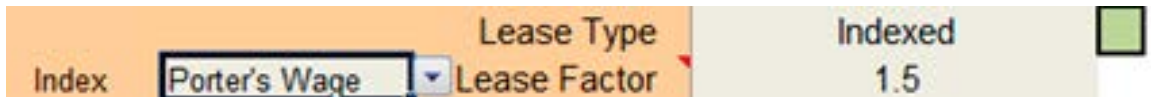

"Lease Factor" specifies the pennies per penny (e.g., 1.5 means 1.5 times the penny change in wage, meaning that if porter's hourly wage increases by 1 penny then rent increases by $1^{\star} 1.5=1.5$ pennies per foot); to change the default porter's wage, please find Porter's Wage Index Settings in the "Cal" tab and adjust the hourly wage for each year accordingly.

$\begin{array}{cc}\begin{array}{c}\text { Porter's Wage Index Settings } \\ \text { Year }\end{array} & \begin{array}{c}\text { Hourly Wage } \\ 1\end{array} \\ 2 & \$ 22.94 \\ 3 & \$ 23.39 \\ 4 & \$ 24.89 \\ 5 & \$ 24.73\end{array}$

- $\quad$ Asking Rent: Landlord's asking base rent in dollars per square foot per year. You can simply use the market rent from the "Market Information" panel if the asking rent is not available.

- $\quad$ Offering Rent: Tenant's offered base rent in dollars per square foot per year with no concessions offered (i.e., no TI, no move-in allowance, and no free rent). Note that the difference between asking rent and offering rent serves as the foundation of the free rent calculations. In essence, the free rents and other concessions are designed such that the cost of the lease is equivalent with tenant offering rent.

- Discount Rate: Tenant's borrowing rate or the potential yield for other investments with similar risk in the capital market over the lease term (also known as the opportunity cost of capital). The discount rate is used to compute the present value of the lease and its effective rent. The tool assumes the same discount rate for both landlord and tenant.

- $\quad$ Free Rent Timing: By default the free rent period is given upfront, but it can be pushed back to the end of the lease term by changing it to "End of the Lease," or it can be spread out in alternate months by selecting "In Alternate Months."

- Upfront Concession Options: The default option "Additional Lump-sum" assumes free rent is the major concession offered in the lease. Because the free rent period uses integers, the residual will be stated as the additional concession amount in a lump sum.

\section{Step 3. Interpreting the Results}

\section{Cash Flow Table}

The cash flow table on the top right panel (shown at right) shows the monthly net cash flow of the lease beginning at the specified commencement date for the specified space.

Average Annual Rent

The bottom left panel shows the average net rent per square foot for each year over the lease term, considering free rents, as shown below.

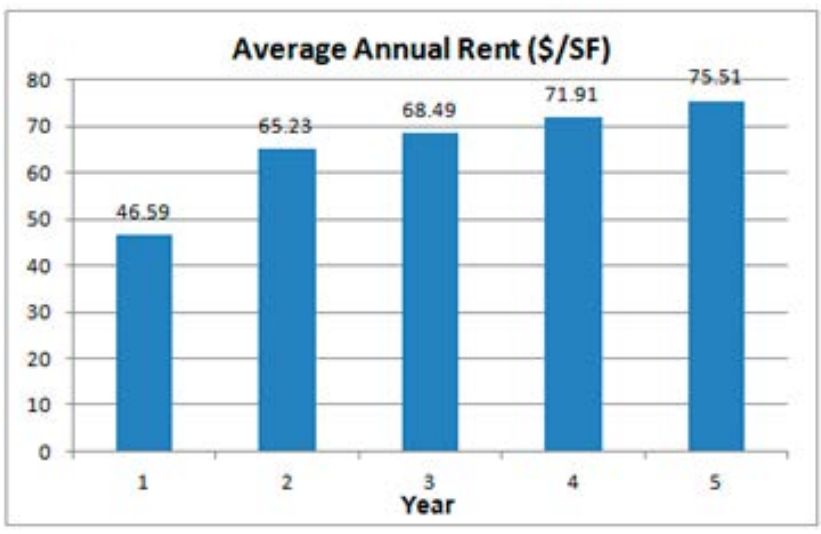

\begin{tabular}{|c|c|c|c|}
\hline Date & Year & Month & Cash Flows \\
\hline $1 / 1 / 2013$ & 1 & 1 & $-\$ 70,000,00$ \\
\hline $2 / 1 / 2013$ & & 2 & $\$ 0.00$ \\
\hline $3 / 1 / 2013$ & & 3 & $\$ 51,766.67$ \\
\hline $4 / 1 / 2013$ & & 4 & $\$ 51,766.67$ \\
\hline $5 / 1 / 2013$ & & 5 & $\$ 51,766.67$ \\
\hline $6 / 1 / 2013$ & & 6 & $\$ 51,766.67$ \\
\hline $7 / 1 / 2013$ & & 7 & $\$ 51,766.67$ \\
\hline $8 / 1 / 2013$ & & 8 & $\$ 51,766.67$ \\
\hline 9/1/2013 & & 9 & $\$ 51,766.67$ \\
\hline $10 / 1 / 2013$ & & 10 & $\$ 51,766.67$ \\
\hline $11 / 1 / 2013$ & & 11 & $\$ 51,766.67$ \\
\hline $12 / 1 / 2013$ & & 12 & $\$ 51,766.67$ \\
\hline $1 / 1 / 2014$ & 2 & 13 & $\$ 54,355.00$ \\
\hline $2 / 1 / 2014$ & & 14 & $\$ 54,355.00$ \\
\hline $3 / 1 / 2014$ & & 15 & $\$ 54,355.00$ \\
\hline 4/1/2014 & & 16 & $\$ 54,355.00$ \\
\hline $5 / 1 / 2014$ & & 17 & $\$ 54,355.00$ \\
\hline $6 / 1 / 2014$ & & 18 & $\$ 54,355.00$ \\
\hline 7/1/2014 & & 19 & $\$ 54,355.00$ \\
\hline $8 / 1 / 2014$ & & 20 & $\$ 54,355.00$ \\
\hline $9 / 1 / 2014$ & & 21 & $\$ 54,355.00$ \\
\hline $10 / 1 / 2014$ & & 22 & $\$ 54,355.00$ \\
\hline $11 / 1 / 2014$ & & 23 & $\$ 54,355.00$ \\
\hline $12 / 1 / 2014$ & & 24 & $\$ 54,355.00$ \\
\hline $\begin{array}{l}1 / 1 / 2015 \\
\text { ?/2 ר15 }\end{array}$ & & 25 & $\begin{array}{l}\$ 57.072,75 \\
\$ \quad 77 \% \cdot 5\end{array}$ \\
\hline
\end{tabular}

The Center for Real Estate and Finance • Cornell University 


\section{Free Rent Results}

The center panel of the tool shows three results: (1) the computed free rent periods, (2) additional upfront concessions, and (3) the effective rent following free rent implementation.

The free rent computation report shown here corresponds to the selection in "Upfront Concession Options." If you select "Additional Lump-sum," the suggested upfront concession amount will be given along with free rent to resolve the rounding error problem, because free rent period is always given as an integer. Finally the effective rent (per square foot) is computed, taking into consideration all lease features including free rent, step-up, and lease term.

If you also want to include and customize other concession types such as TIs or move-in allowance, you can incorporate them into free rent calculations by just clicking the "Upfront Concession Options" to "Let Me Specify." Then specify tenant improvements in dollars per square foot and the aggregate amount of move-in allowance. You will get the maximum (rounded) free rent period in response to your additional specified concessions. Please note that the free rent period is then calculated assuming that the tenant is indifferent between paying asking rent with free rent, Tis, and move-in allowance, and paying offering rent without any concessions.

\begin{tabular}{c|c} 
Upfront Concession Options & Let Me Specify \\
Tenant Improvement (\$/SF) & $\$ 5.00$ \\
Total Move-in Allowance & $\$ 20,000.00$ \\
\hline
\end{tabular}

\begin{tabular}{|c|}
\hline Free Rent Period (Month) \\
\hline 2 \\
\hline Effective Rent (S/SF) \\
$\$ 63.61$
\end{tabular}




\section{Calculation Concept}

The computational method embedded in the "Cal" tab for calculating the number of free rents is illustrated with the following example. Consider a 5-year (60 month) flat lease for a 10,000 s.f. store with landlord's asking rent of $\$ 60 / \mathrm{SF}$ per year $(\$ 5 / \mathrm{month} / \mathrm{SF})$ and tenant's offering rent of $\$ 54 / \mathrm{SF}$ per year $(\$ 4.5 / \mathrm{month} / \mathrm{SF})$. Assume an annual discount rate of $12 \%(1 \%$ monthly), and rental payment occurs at the end of each month. The goal of using free rent is to keep the $\$ 60$ nominal rate while eventually having $\$ 54$ as the effective rent. We assume the free rent is scheduled at the beginning of the lease.

Let $\mathrm{N}_{1}$ be the number of lease months; $\mathrm{N}_{2}$, the number of free rent months; $\mathrm{C}_{1}$, the amount of monthly cash flow based on landlord's asking rent; $C_{2}$, the amount of monthly cash flow based on tenant's offering rent; $i$, the monthly discount rate; and PV, the present value of an annuity. With the rental offer described above, $N_{1}=60, C_{1}=5, C_{2}=4.5$, and $i=1 \%$,

$$
\begin{aligned}
& P V_{\mathrm{C}_{1}}=\sum_{n=1}^{N_{1}} \frac{C_{1}}{(1+i)^{n}}=C_{1}\left[\frac{1-(1+i)^{-N_{1}}}{i}\right]=5\left[\frac{1-(1+.01)^{-60}}{.01}\right]=224.78 \\
& P V_{C_{2}}=\sum_{n=1}^{N_{1}} \frac{C_{2}}{(1+i)^{n}}=C_{2}\left[\frac{1-(1+i)^{-N_{1}}}{i}\right]=4.5\left[\frac{1-(1+.01)^{-60}}{.01}\right]=202.30
\end{aligned}
$$

Essentially, the amount of $\mathrm{PV}_{C_{1}}$ in excess of $\mathrm{PV}_{C_{2}}$ is the present value of free rents, or $P V$ of free rents or $P V_{f}=P_{C_{1}}-P_{C_{2}}$ $=22.48$.

Here, the free rent $\mathrm{N}_{2}$ is equivalent with the number of months of landlord's asking rent at the beginning of lease that would yield the $\mathrm{PV}_{\mathrm{f}}$. This means that

$$
P V_{f}=\sum_{n=1}^{N_{2}} \frac{C_{1}}{(1+i)^{n}}=C_{1}\left[\frac{1-(1+i)^{-N_{2}}}{i}\right]=5\left[\frac{1-(1+.01)^{-N_{2}}}{.01}\right]=22.48
$$

We then get

$$
N_{2}=\frac{\left[\ln C_{1}-\ln \left(C_{1}-P V_{f} * i\right)\right]}{\ln (1+i)}=\frac{[\ln 5-\ln (5-22.48 * .01)]}{\ln (1+.01)}=4.62
$$

Therefore the free rent period is 4 months (rounded down to the nearest integer). The additional upfront concession is computed using 0.62 , the residual value between actual free rent of 4.62 months and the rounded calculation of 4 months. With 10,000 s.f. leased space, the tenant should receive additional upfront concession of $\$ 29,701$ or $\$ 2.97$ per square foot.

$$
10,000 \times\left(P V_{f}-\sum_{n=1}^{4} \frac{C_{1}}{(1+i)^{n}}\right)=10,000(22.48-19.51)=29,701
$$

Because the lease type in this example is a flat lease, the effective rent is essentially the tenant's offering rent, $\$ 54 / \mathrm{SF}$ per year. 


\section{CREF Industry Fellows}

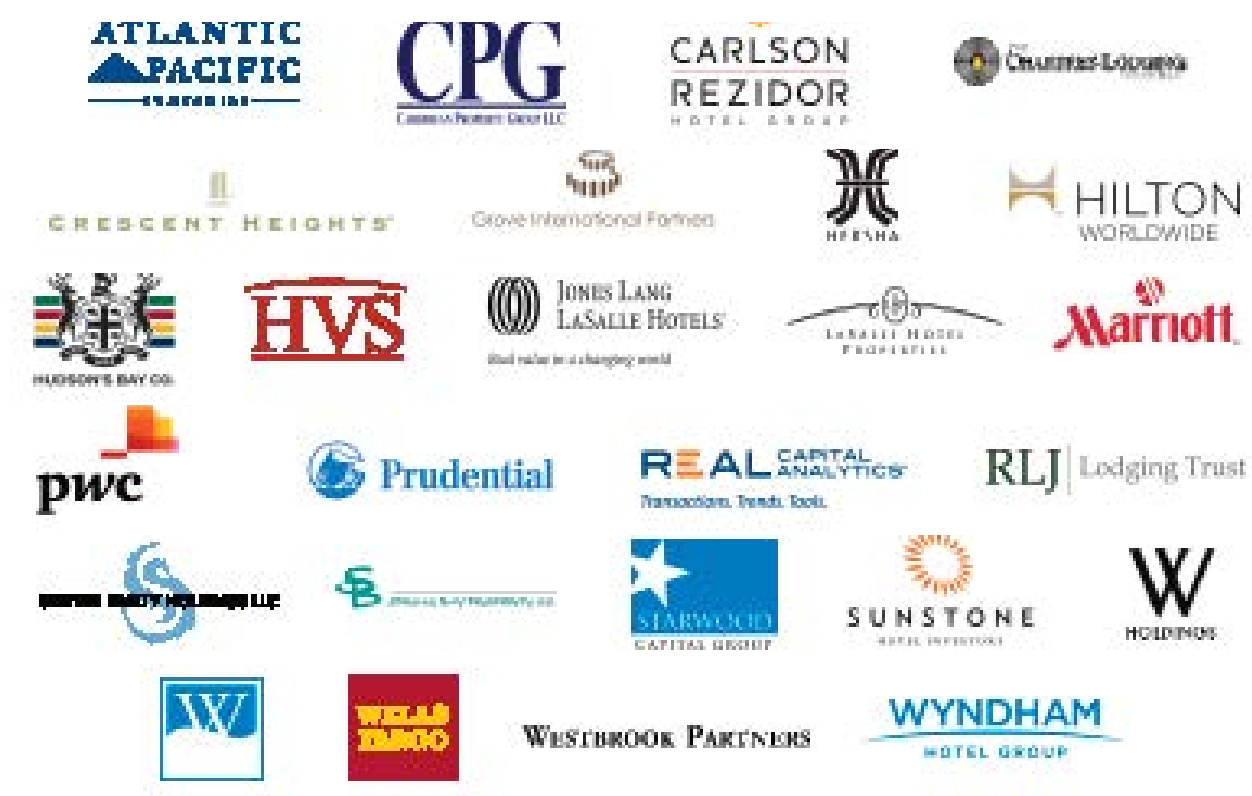

\section{CREF Advisory Board}

\section{Arthur Adler}

Managing Director and CEO-Americas

Jones Lang LaSalle Hotels

Richard Baker

President and CEO

National Realty \& Development Corp

Michael Barnello

President \& COO

LaSalle Hotel Properties

Scott Berman

Principal, Industry Leader

PricewaterhouseCoopers

Vernon Chi

Senior Vice President

Wells Fargo

\section{Howard Cohen}

President \& Chief Executive Officer

Atlantic | Pacific Companies

Jeff Dallas

Senior Vice President, Development

Wyndham Hotel Group

Joel Eisemann

SVP \& CEO

InterContinental Hotels Group

Kevin Fitzpatrick

Managing Director

Spring Bay Property Company

Russell Galbut

Managing Principal

Crescent Heights

\section{Kate Henrikson}

Senior Vice President Investments

RLJ Lodging Trust

Nancy Johnson

Executive Vice President

Carlson Rezidor Hotel Group

Rob Kline

President \& Co-Founder

The Chartres Lodging Group

Mark Lipschutz

Founder and Chief Executive Officer

Caribbean Property Group LLC

\section{Michael Medzigian}

Chairman \& Managing Partner

Watermark Capital Partners

Scott E. Melby

Executive Vice President, Development

Planning \& Feasibility

Marriott International

Chang S. Oh

Managing Director

The Mega Company

Michael Profenius

Managing Director

Warburg Pincus LLC

David Rosenberg

Chief Executive Officer

Sawyer Realty Holdings

Steve Rushmore

President and Founder

HVS Global Hospitality Services

Jay Shah

Chief Executive Officer

Hersha Hospitality Trust

J. Allen Smith

Chief Executive Officer

Prudential Real Estate Investors

\section{Robert Springer}

Senior Vice President-Acquisitions

Sunstone Hotel Investors

Susheel Torgalkar

Chief Operating Officer

Westbrook Partners

Robert White

President

Real Capital Analytics

Conley Wolfsinkel

Strategic Management Consultant

W Holdings

\section{Dexter Wood}

SVP, Global Head-Business \&

Investment Analysis

Hilton Worldwide

Daniel Yih

Chief Operating Officer

Starwood Capital Group
Center for Real Estate and Finance Reports, Vol. 3, No. 2 (February 2014)

(c) 2014 Cornell University. This report may not be reproduced or distributed without the express permission of the publisher.

The CREF Report series is produced for the benefit of the hospitality real estate and finance industries by The Center for Real Estate and Finance at Cornell University

Daniel Quan, Executive Director Melissa Carlisle, Program Manager Glenn Withiam, Executive Editor Alfonso Gonzalez, Executive Director of Marketing and Communications

Center for Real Estate and Finance Cornell University

School of Hotel Administration 389 Statler Hall Ithaca, NY 14853

Phone: 607-255-6025

www.cref.cornell.edu 


\section{ABOUT THE AUTHORS}

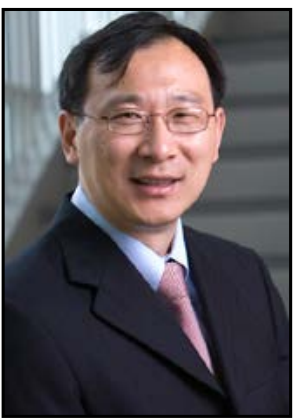

Peng (Peter) Liu, Ph.D., is an associate professor of real estate at the Cornell University School of Hotel Administration.

Luoyi Su is a student at the Cornell University College of Arts and Science.
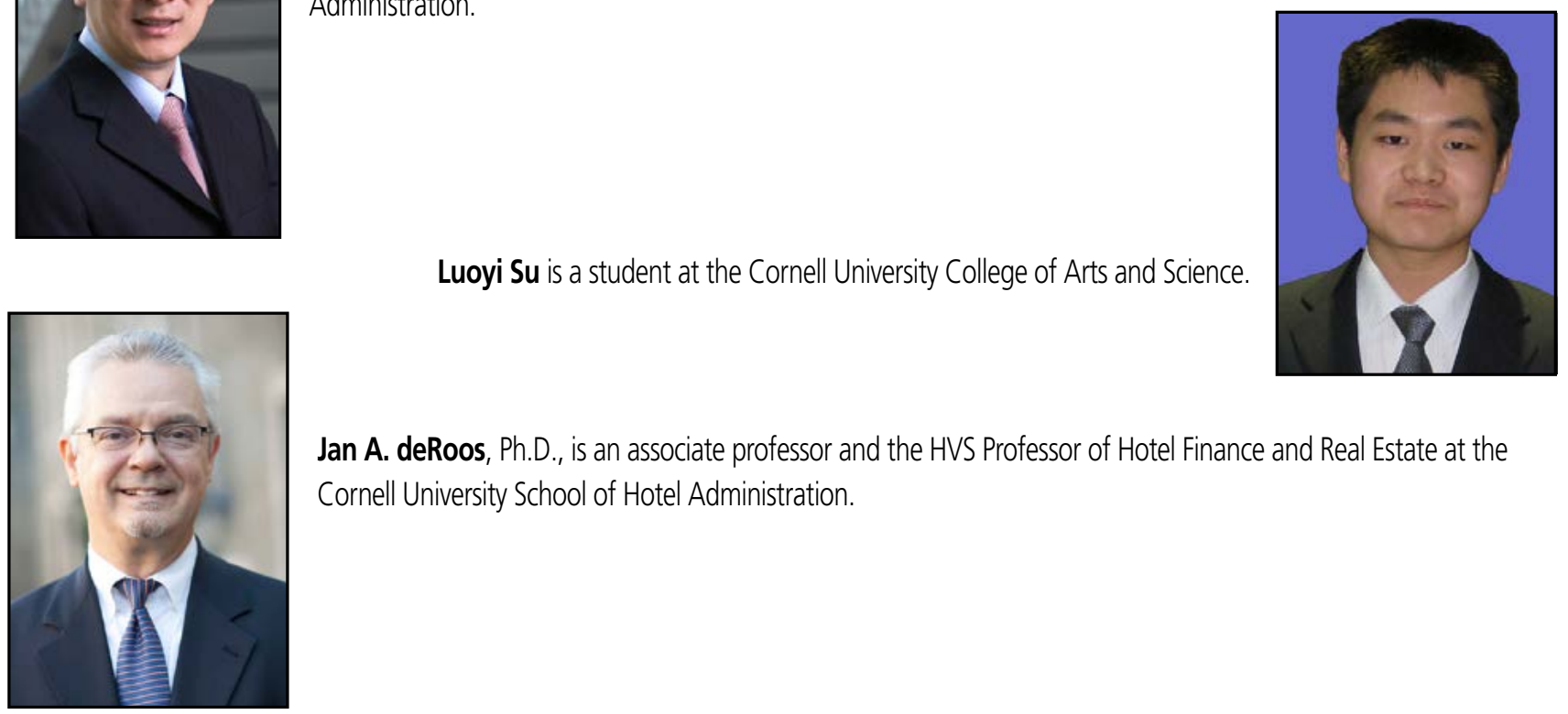

Jan A. deRoos, Ph.D., is an associate professor and the HVS Professor of Hotel Finance and Real Estate at the Cornell University School of Hotel Administration. 